\title{
PENGARUH PENGHARGAAN FINANSIAL, PERTIMBANGAN PASAR KERJA, DAN LINGKUNGAN KERJA TERHADAP PEMILIHAN KARIR SEBAGAI AKUNTAN PADA MAHASISWA AKUNTANSI DI JAKARTA
}

\author{
Zen Amalia, Achmad Fauzi, Mardi \\ Fakultas Ekonomi, Universitas Negeri Jakarta \\ Email : amaliamel.zen@gmail.com
}

\begin{abstract}
This study aims to determine whether there is an influence between financial rewards, labor market considerations, and work environment on career choices as accountants for accounting students in Jakarta by using a survey method. The population in this study were 518 accounting students at the University of Jakarta. The sampling technique used proportional random sampling so that the sample amounted to 226 students. The data analysis technique used is multiple regression analysis. Based on the results of the research that partially shows that there is a positive and significant influence between financial rewards and career choice as an accountant, job market consideration variables have a positive and significant influence on career choice as an accountant, work environment variables have a positive and significant effect on career choice as an accountant. . Meanwhile, simultaneously it shows that financial rewards, job market considerations, and work environment influence career choices as accountants. The magnitude of the influence of the variables of financial rewards, labor market considerations, and work environment on career choices as accountants is $42.4 \%$, while the remaining $57.6 \%$ can be described by other variables not examined by the researcher.
\end{abstract}

Keyword: Financial Rewards, Job Market Considerations, Work Environment, Career Choices as Accoutant

\section{PENDAHULUAN}

Dengan perkembangan teknologi informasi yang semakin maju, masyarakat semakin mendapat perhatian untuk meningkatkan kualitas diri dalam bersaing di dunia kerja. Tentunya mahasiswa harus bisa mempersiapkan perencanaan karirnya di masa mendatang dengan apa yang menjadi harapan dan keinginan dari pilihan karir yang ditekuninya, tidak terkecuali untuk mahasiswa akuntansi. Menjadi seorang akuntan dinilai memiliki peran penting untuk membangun tranparansi dan keakuratan laporan keuangan di Indonesia. Profesi akuntan memiliki tugas untuk melakukan proses pengambilan keputusan yang strategis bersifat integritas dan informasi yang kredibel atau dapat dipercaya (Espa et al., 2016).

Saat ini dunia sedang mengalami perubahan yang drastis akibat perkembangan teknologi digital dan juga dipercepat adanya pandemi Covid-19 sehingga diperlukan adanya profesi akuntan yang professional untuk membantu menstabilkan dan meningkatkan tata kelola perusahaan yang terdaftar di BUMN dan kinerjanya yang mengalami penurunan akibat pandemi Covid-19. Mahasiswa yang setelah lulus nantinya memilih karir sebagai seorang akuntan harus bisa membangkitkan perekonomian di masa mendatang (Ikatan Akuntansi Indonesia, N.D.).

Kesuksesan karir mahasiswa akuntansi tergantung pada kemampuan untuk memiliki tingkat keterampilan yang tinggi dalam menghadapi perkembangan perekonomian yang bersifat global, sehingga profesi akuntansi perlu memiliki daya saing yang tinggi jika ingin menarik minat 
mahasiswa yang berkualitas. Cara utama untuk mencapai tujuan ini adalah dengan memperdalam pemahaman tentang faktor yang dapat mempengaruhi pilihan karir mahasiswa (Byrne et al., 2012).

Penelitian ini memiliki tujuan untuk melakukan identifikasi faktor penghargaan finansial, pertimbangan pasar kerja, dan lingkungan kerja yang mempengaruhi pemilihan karir sebagai akuntan pada mahasiswa akuntansi. Hasil penelitian (Hambali et al., 2018) menunjukkan bahwa penghargaan finansial berpengaruh positif namun tidak signifikan terhadap pemilihan karir sebagai akuntan publik, sedangkan untuk lingkungan kerja dan pertimbangan pasar kerja berpengaruh positif signifikan terhadap pemilihan karir sebagai akuntan publik. Sedangkan penelitian yang dilakukan oleh Azhiin \& Sukirno (2018) menunjukkan bahwa terdapat perbedaan pandangan diantara mahasiswa akuntansi yang memilih karir sebagai akuntan publik, akuntan perusahaan, akuntan pemerintah, dan akuntan pendidik mengenai penghargaan finansial, lingkungan kerja, dan pertimbangan pasar kerja menjadi faktor yang secara signifikan dipertimbangkan oleh mahasiswa dalam memilih karir masa depan mereka. Namun disisi lain, mahasiswa tidak secara signifikan mempertimbangkan pelatihan profesional dan nilai-nilai sosial sebagai faktor yang diperhitungkan dalam pemilihan karir. Dari total responden (200 mahasiswa), profesi yang paling disukai mahasiswa adalah sebagai akuntan perusahaan (80 mahasiswa), disusul sebagai akuntan publik (58 mahasiswa), kemudian sebagai akuntan pemerintah (54 mahasiswa) dan paling sedikit adalah sebagai akuntan pendidik ( 8 mahasiswa).

Dalam pemilihan karir terdapat faktor-faktor yang mempengaruhi mahasiswa akuntansi yang akan menjadi faktor utama dalam penelitian ini, antara lain faktor penghargaan finansial, pertimbangan pasar kerja, dan lingkungan kerja. Faktor - faktor tersebut dapat diambil dari penelitian atas pertimbangan dari beberapa peneltian terdahulu. Hasil penelitian terdahulu menyimpulkan bahwa terdapat beberapa perbedaan dari penelitian yang lainnya dalam mempertimbangkan faktor-faktor yang mempengaruhi pemilihan karir sebagai akuntan, dimana faktor-faktor tersebut dijadikan sebagai variabel penelitian. Perbedaaan penelitian ini dengan penelitian yang sebelumnya terletak pada populasi dan sampel sebagai objek penelitian yang berbeda dengan penelitian terdahulu. Penelitian ini menggunakan responden dari mahasiswa S1 program studi akuntansi perguruan tinggi di Jakarta angkatan 2017. Dari hasil penelitian ini diharapkan dapat memberikan manfaat kepada perguruan tinggi program studi S1 akuntansi guna meningkatkan kualitas pengajaran sehingga lulusan mahasiswa akuntansi dapat menjadi pekerja yang intelektual dan siap pakai sesuai kebutuhan pasar.

\section{TINJAUAN LITERATUR}

\section{Teori Persepsi Diri}

Persepsi merupakan sebuah pengalaman tentang objek, kejadian atau hubungan yang di dapat dengan menyimpulkan informasi dan menganalisis pesan (Susanti, 2021). Setiap individu memiliki persepsi yang berbeda, karena persepsi dipengaruhi oleh beberapa faktor, antara lain : 1) faktor pelaku, seseorang yang memandang objek dan menafsirkan yang dipengaruhi karakteristik pribadi mencakup sikap, motif, kepentingan, pengalaman, dan pengharapan. 2) faktor objek, karakteristik yang diperoleh dari target yang diamati sehingga mempengaruhi apa yang dipersespsikan. 3) faktor situasi, meliputi waktu, keadaan tempat kerja, dan sosial (Mu'ah \& Masram, 2014).

\section{Teori Pengharapan}

Teori pengharapan mengatakan bahwa kecenderungan seseorang dalam melakukan tindakan dengan suatu cara tertentu bergantung pada keinginan yang kuat atau pengharapan bahwa tindakan tersebut akan didasarkan terhadap hasil yang diberikan dan ketertarikan bagi setiap individu (Robbins \& Judge, 2017). Artinya, seseorang akan berupaya mendapatkan apa yang diinginkannya 
apabila seseorang sangat menginginkan hal itu maka jalan yang dilalui tampak terbuka untuk dapat memperolehnya.

\section{Pemilihan karir sebagai akuntan}

Pemilihan Karir adalah suatu proses pengembangan jalan terbuka dalam kehidupan individu dan hal ini berbeda perspektif dengan menggunakan pendekatan perilaku (behavioristik) yang menjelaskan bahwa saat seseorang berada pada proses pilihan karir yang mana dalam melakukan pilihan karirnya terdapat intervensi atau tekanan dan tidak memperhatikan karir mana yang dipilih individu (Malik, 2016). Pernyataan ini diperkuat oleh (Marliyah et al., 2004) Pemilihan Karir merupakan suatu proses yang kompleks dan beragam ketika remaja mengarahkan diri kepada suatu tahap baru sesuai dengan keinginan dalam kehidupannya yang diimplementaskan dengan memperhatikan konsep diri dan latar belakang individu sampai pembuatan keputusan karir. Menurut Saputra (2018) yang menyatakan bahwa pilihan karir merupakan proses atau aktivitas individu yang bertujuan untuk mempersiapkan diri memasuki dunia kerja melalui rangkaian aktivitas tersturuktur yang ditargetkan, sehingga mampu melaksanakan pemilihan karir yang sesuai dengan apa yang diharapkan atau diinginkan.

Menurut Mathis dan Jackson (Kartono, 2019) ada empat karakteristik individual umum yang mempengaruhi seseorang dalam pilihan karir yaitu Minat, Citra diri, Kepribadian, dan Latar belakang sosial. Menurut (D.Viviers \& Schalkwyk, 2002) terdapat faktor-faktor yang mempengaruhi pilihan karir seseorang dengan menyesuaikan tipe pribadi dengan membandingkan persyaratan pekerjaan, yaitu : Minat, Kepribadian, dan Latar belakang sosial. Sedangkan menurut (Meddour et al., 2016) terdapat beberapa faktor penting yang dapat berkontribusi dalam keputusan pilihan karir meliputi : perencanaan karir yang efisien, pemilihan sikap yang konsisten, kristalisasi sifat, kepribadian seseorang, status sosial ekonomi (SEM), kepercayaan yang rusak, pengetahuan diri, efikasi diri, reputasi karir, minat, jenis kelamin, dan tipe kepribadian.

\section{Indikator dari Pemilihan Karir sebagai Akuntan}

Berdasarkan pendapat beberapa ahli diatas, maka peneliti menggunakan indikator minat, kepribadian, dan latar belakang sosial sebagai dasar untuk mengukur variabel pemilihan karir sebagai akuntan.

\section{Penghargaan Finansial}

Kompensasi dapat diartikan sebagai semua bentuk pengembalian (return) finansial dan imbalan-imbalan yang diperoleh karyawan sebagai bagian dari sebuah hubungan kepegawaian (Suprihanto, 2018). Menurut (Mulyadi, 2007) dalam bukunya menjelaskan bahwa sistem penghargaan didefinisikan sebagai suatu alat pengendalian penting yang digunakan oleh perusahaan untuk memotivasi seseorang agar mencapai tujuan perusahaan (bukan tujuan individual) dengan menerapkan perilaku sesuai dengan yang diharapkan oleh perusahaan (bukan perilaku yang disukai oleh pribadi sendiri). Menurut (Hariandja, 2002) gaji merupakan suatu bentuk balas jasa berupa uang yang diterima oleh karyawan sebagai dampak dari adanya kedudukan/posisi jabatan seorang pegawai yang sudah memberikan kontribusinya dalam menyelesaikan pekerjaannya guna untuk mencapai tujuan organisasi atau perusahaan.

Berdasarkan pendapat diatas, bahwa penghargaan finansial adalah alat untuk memotivasi karyawan dalam bentuk balas jasa berupa uang, bonus, tunjangan, dana pensiun yang diberikan karena memiliki kontribusi kepada perusahaan atas pekerjaannya, memiliki keterampilan dan kinerja dalam memabantu organisasi atau perusahaan untuk mencapai tujuan.

Menurut Hermino (2013) menjelaskan indikator dalam penghargaan finansial, yaitu 1) Pembayaran keuangan langsung dalam bentuk gaji, upah, insentif, komisi, dan bonus. 2) 
Pembayaran tidak langsung dalam bentuk tunjangan keuangan seperti asuransi dan uang liburan yang dibayarkan oleh perusahaan.

Hal ini serupa dengan pendapat yang dikemukakan oleh (Susanto, 2017) bahwa indikator dalam penghargaan finansial antara lain : 1) Kompensasi finansial yang terdiri dari upah atau gaji tetap yang diterima, bonus, uang lembur, dan hadiah. 2) Kompensasi non finansial terdiri dari pemberian jaminan atau tunjangan kesehatan dan pemberian penghargaan khusus.

Berikut pula dengan pendapat Kaswan (Marnisah, 2019) bahwa kompensasi terdiri dari tiga komponen : 1) Kompensasi dasar, yaitu kompensasi yang diterima secara rutin dalam bentuk upah/gaji. 2) Kompensasi insentif, yaitu pemberian imbalan kepada pekerja atau buruh atas kinerja yang baik. Insentif ini dapat berupa bonus dan bagi untung. 3) Kompensasi tunjangan yang meliputi program asuransi kesehatan, liburan, dan lain-lain.

Faktor yang mempengaruhi Penghargaan Finansial

Menurut (Rafsandjani \& Firdian, 2017) menjelaskan bahwa faktor-faktor yang dapat mempengaruhi pemberian penghargaan finansial berupa kompensasi yaitu : 1) Faktor Internal Organisasi yang terdiri dari dana organisasi dan serikat pekerja. 2) Faktor Pribadi Karyawan, yang meliputi produktivitas kerja, posisi dan jabatan, pendidikan dan pengalaman, jenis dan sifat pekerjaan. 3) Faktor Eksternal, meliputi penawaran dan permintaan kerja, biaya hidup, kebijakan pemerintah, dan kondisi perekonomian nasional.

Menurut Utama (2020), faktor-faktor yang mempengaruhi tingkat upah dan gaji, antara lain : 1) Penawaran dan permintaan tenaga kerja, 2) Labor union (organisasi pekerja), 3) Ability to pay (kemampuan membayar), 4) Produktivitas atau prestasi, 5) Cost of living (biaya hidup), 6) Kebijakan pemerintah.

\section{Indikator dari Penghargaan Finansial}

Berdasarkan pendapat beberapa ahli diatas, maka peneliti menggunakan indikator gaji, bonus, dan tunjangan sebagai dasar untuk mengukur variabel penghargaan finansial.

\section{Pertimbangan Pasar Kerja}

Pasar kerja merupakan sarana yang mengkoordinasikan pertemuan antara pencari kerja dan perusahaan yang memerlukan tenaga kerja. Jadi di pasar kerjalah yang mengkoordinasikan pertemuan antara pencari kerja dan perusahaan yang memerlukan tenga kerja (Suindari \& Purnama Sari, 2018). Kemudian menurut (Malik, 2018) Pasar Kerja adalah interaksi antara permintaan dan penawaran tenaga kerja atau seluruh aktivitas dari pelaku-pelaku yang mempertemukan pencari kerja dengan perusahaan yang menyediakan lowongan kerja. Sedangkan menurut (Abbott, 2013) pasar tenaga kerja adalah membeli, menjual, dan memberikan harga untuk satu orang jasa ekonomi menengah yang terjadi dalam pasar tenaga kerja pada sisi permintaan dan penawaran.

Berdasarkan penjelasan dari beberapa ahli, bahwa pertimbangan pasar kerja merupakan suatu hal yang dapat mengkoordinasikan pertemuan antara pencari kerja dengan perusahaan yang memerlukan tenaga kerja sehingga pertimbangan pasar kerja turut menjadi faktor yang harus dipertimbangkan sebelum memilih pekerjaan.

Menurut (Setianto \& Harahap, 2017) dalam mempertimbangkan pasar kerja ada hal-hal yang perlu diperhatikan yaitu 1) Tersedianya lapangan kerja, 2) Keamanan kerja, 3) fleksibilitas karir, dan 4) Peluang promosi. Dalam penelitian (Andini \& Amboningtyas, 2020) indikator pertimbangan pasar kerja terdiri dari empat aspek, yang meliputi tersedianya lapangan kerja, keamanan kerja, fleksibilitas karir, dan kesempatan promosi. Begitu pula dengan pendapat (Asmoro et al., 2016) dalam penelitiannya mengukur pertimbangan pasar kerja dengan indikator 
sebagai berikut : 1) keamanan kerja, 2) kemudahan mengakses lowongan pekerjaan, 3) fleksibilitas karir, dan 4) kesempatan promosi

\section{Faktor yang mempengaruhi Pertimbangan Pasar Kerja}

Menurut (Prieto, 2020) terdapat teori pasar tenaga kerja yang terbagi menjadi dua sektor:

1) Sektor primer : pasar kerja ditandai dengan upah tinggi, keamanan kerja, dan mobilitas kerja.

2) Sektor sekunder : pasar kerja ditandai dengan dengan upah rendah, pekerjaan tidak aman dan sedikit atau bahkan tidak ada mobilitas pekerjaan.

Menurut (Pearce \& Robinson, 2008) akses suatu perusahaan kepada karyawan yang diperlukan terutama dipengaruhi empat faktor, yaitu :

1) Reputasi perusahaan sebagai pemberi kerja merupakan hal yang penting dari kemampuannya untuk memenuhi kebutuhannya akan karyawan.

2) Tingkat pengangguran setempat, menjadi suatu pasokan tenaga kerja ahli dan berpengalaman yang tersedia langsung dan bervariasi sesuai dengan tahap pertumbuhan komunitas.

3) Ketersediaan tenaga kerja dengan keahlian yang diperlukan, keahlian individu dalam mencari pekerjaan terspesialisasi sehingga perlu adanya relokasi untuk mempertahankan pekerjaan dan kompensasi yang dituntut oleh keahlian tersebut.

4) Hubungan perusahaan dengan serikat kerja, dengan adanya serikat kerja mewakili para tenaga kerja dalam melakukan negosisasi dengan pemberi kerja melalui proses tawar-menawar secara bersama

\section{Indikator dari Pertimbangan Pasar Kerja}

Berdasarkan pendapat beberapa ahli diatas, maka peneliti menggunakan indikator keamanan kerja, tersedianya lapangan pekerjaan, fleksibilitas karir, dan kesempatan promosi sebagai dasar untuk mengukur variabel pertimbangan pasar kerja.

\section{Lingkungan Kerja}

Lingkungan Kerja adalah suatu keadaan tempat kerja seorang pegawai yang meliputi lingkungan fisik dan non fisik yang dapat mempengaruhi pegawai dalam menjalankan aktivitas dan tugas yang dibebankan (Riyadi, 2018). Menurut (Afandi, 2016) lingkungan kerja dalam suatu perusahaan sangat penting untuk diperhatikan pihak manajemen. Dalam melaksanakan proses produksi yang dilakukan karyawan akan berpengaruh terhadap lingkungan kerja. Lingkungan kerja adalah suasana di mana karyawan melakukan kegiatan rutin tiap harinya yang memberikan suasana kondusif, rasa aman, dan dapat bekerja secara optimal. Sedangkan menurut (Bahri, 2018) lingkungan kerja adalah segala sesuatu yang ada disekitar karyawan yang dapat mempengaruhi dirinya dalam melakukan aktivitas pekerjaannya.

Dari beberapa pendapat di atas, dapat disimpulkan bahwa lingkungan kerja merupakan seseorang yang melakukan aktivitas pekerjaannya baik dalam bentuk fisik maupun non fisik yang dapat mempengaruhi produktivitas dan kinerja karyawan. Lingkungan kerja yang nyaman memungkinkan para pegawai untuk bekerja secara optimal dan pegawai yang merasa senang dalam lingkungan kerjanya akan melakukan aktivitas dengan waktu kerja yang dipergunakannya secara efektif sehingga mengalami peningkatan prestasi kerja pegawai.

Dalam bukunya Nitisemito, indikator lingkungan kerja adalah suasana kerja, hubungan dengan rekan kerja, hubungan antara bawahan dan pemimpin, ketersediaan fasilitas untuk karyawan (Nikmatin et al., 2019). Selanjutnya pendapat tersebut selaras dengan penelitian (Iis et al., 2019) mengemukakan indikator dalam lingkungan kerja adalah suasana kerja, hubungan dengan rekan kerja, hubungan bawahan dengan pimpinan, dan ketersediaan fasilitas bagi karyawan. Sedangkan, selaras dengan pendapat (Prihantoro, 2019) mengungkapkan indikator 
lingkungan kerja meliputi hubungan antar karyawan, suasana kerja, dan fasilitas-fasilitas kerja karyawan.

\section{Faktor yang mempengaruhi Lingkungan Kerja}

Menurut (Wibowo, 2020) terdapat macam-macam lingkungan kerja yang dibagi menjadi 2 yaitu : 1) Lingkungan fisik adalah kondisi lingkungan yang berwujud fisik yang berada disekitar tempat kerja karyawan melakukan aktivitas pekerjaannya dan dapat mempengaruhi secara langsung maupun tak langsung. 2) Lingkungan non fisik berarti seluruh kondisi lingkungan yang berkaitan dengan hubungan pekerjaan antara pekerja dengan pekerja maupun pekerja dengan atasan atau dengan bawahannya.

Menurut Marwansyah (Surajiyo et al., 2020) menjelaskan terdapat faktor-faktor yang mempengaruhi lingkungan kerja yaitu : 1) Lingkungan eksternal merupakan kekuatan - kekuatan utama dalam suatu perusahaan yang dapat berpotensi untuk mempengaruhi keberhasilan suatu perusahaan dalam mencapai tujuannya. 2) Lingkungan internal merupakan kondisi umum yang terdapat dalam suatu perusahaan yang dapat mempengaruhi manajemen perusahaan.

\section{Indikator dari Lingkungan Kerja}

Jadi dapat disimpulkan bahwa indikator yang dapat digunakan terkait lingkungan kerja pada pemilihan karir sebagai akuntan yaitu suasana kerja, hubungan dengan rekan kerja, dan ketersediaan fasilitas kerja.

\section{METODE PENELITIAN}

\section{Perumusan Hipotesis}

Dari penjelasan deskripsi konseptual dan teori yang diuraikan dalam penelitian ini, peneliti merumuskan hipotesis penelitian sebagai berikut:

1) Ada pengaruh antara penghargaan finansial terhadap pemilihan karir sebagai akuntan

2) Ada pengaruh antara pertimbangan pasar kerja terhadap pemilihan karir sebagai akuntan

3) Ada pengaruh antara lingkungan kerja terhadap pemilihan karir sebagai akuntan

4) Ada pengaruh antara penghargaan finansial, pertimbangan pasar kerja, dan lingkungan kerja terhadap pemilihan karir sebagai akuntan

Jenis penelitian ini mengguakan kuantitatif dengan metode survei. Independen variabel dalam penelitian ini adalah penghargaan finansial, pertimbangan pasar kerja, dan lingkungan kerja, sedangkan variabel dependen adalah pemilihan karir sebagai akuntan. Populasi adalah suatu wilayah yang digeneralisasi dengan terdiri atas objek/subjek yang memiliki besaran dan karakteristik tertentu yang dilakukan peneliti untuk dikumpulkan kemudian dibuat dengan hasil kesimpulan (Sugiyono, 2017, hlm. 61). Populasi dalam penelitian ini adalah mahasiswa S1 akuntansi universitas di Jakarta. Populasi terjangkau dalam penelitian ini adalah mahasiswa S1 Program Studi Akuntansi angkatan 2017 yang terdapat pada Universitas Negeri Jakarta, Universitas Pembangunan Nasional Veteran Jakarta, dan Universitas Mercubuana, dengan rincian sebagai berikut:

\section{Tabel 1}

\section{Rincian Populasi Terjangkau}

\begin{tabular}{|c|l|c|}
\hline No. & \multicolumn{1}{|c|}{ Perguruan Tinggi } & Populasi \\
\hline 1. & Universitas Negeri Jakarta & 85 \\
\hline 2. & Universitas Pembangunan Nasional Veteran Jakarta & 248 \\
\hline 3. & Universitas Mercubuana & 185 \\
\hline \multicolumn{2}{|c|}{ Total } & 518 \\
\hline
\end{tabular}

Sumber : data diolah oleh peneliti (2020) 
Dalam penelitian ini teknik pengambilan sampel yang digunakan adalah proportional random sampling. Penentuan sampel dalam penelitian in menggungakan rumus slovin. Jadi diketahui bahwa julah sampel yang diperoleh dalam penelitian ini adalah 226 mahasiswa. Dalam pengumpulan data menggunakan data primer berupa kuesioner yang telah diuji validitas dan reliabilitasnya. Teknik analisis data yang digunakan adalah statistik deskriptif, uji persyaratan analisis, dan uji hipotesis.

\section{Teknik Pengumpulan Data}

Penelitian ini menggunakan 4 variabel terdiri dari penghargaan finansial (X1), pertimbangan pasar kerja (X2), lingkungan kerja (X3), dan pemilihan karir sebagai akuntan (Y). Penelitian ini merupakan penelitian kuantitaif dan jenis pengumpulan data yang dikumpulkan menggunakan metode kuesioner. Sumber data yang digunakan adalah data primer. Sumber data primer bisa langsung dikumpulkan kepada peneliti.

\section{HASIL DAN PEMBAHASAN}

\subsection{Hasil Penelitian}

\section{Deskriptif Statistik}

Dari total 226 responden karir yang paling diingiankan mahasiswa akuntansi yaitu memilih karir sebagai akuntan perusahaan yaitu sebesar 107 mahasiswa, disusul sebagai akuntan publik sebesar 69 mahasiswa, kemudian sebagai akuntan pemerintah sebanyak 45 mahasiswa dan terakhir akuntan pendidik yang memiliki minat karir paling sedikit yaitu berjumlah 5 mahasiswa.

\section{Data Pemilihan Karir sebagai Akuntan}

Berdasarkan data yang dikumpulkan oleh peneliti, beberapa statistic deskriptif variabel Y (pemilihan karir sebagai akuntan) akan dijelaskan.

\section{Tabel 2}

Statistik Deskriptif Variabel Y (Pemilihan Karir Sebagai Akuntan)

\begin{tabular}{|c|c|c|c|c|c|c|c|c|c|}
\hline \multicolumn{10}{|c|}{ Descriptive Statistics } \\
\hline & $\begin{array}{c}\mathrm{N} \\
\text { Statisti } \\
\mathrm{C}\end{array}$ & $\begin{array}{l}\text { Ran } \\
\text { ge } \\
\text { Stat } \\
\text { istic }\end{array}$ & $\begin{array}{c}\text { Mini } \\
\text { mum } \\
\text { Statist } \\
\text { ic }\end{array}$ & $\begin{array}{c}\text { Maxi } \\
\text { mum } \\
\text { Statist } \\
\text { ic }\end{array}$ & $\begin{array}{c}\text { Sum } \\
\text { Statistic }\end{array}$ & $\begin{array}{r}\text { Mea } \\
\text { Statistic }\end{array}$ & $\begin{array}{l}\text { Std. } \\
\text { Error }\end{array}$ & $\begin{array}{c}\text { Std. } \\
\text { Deviatio } \\
\mathbf{n} \\
\text { Statistic }\end{array}$ & $\begin{array}{c}\text { Varianc } \\
\mathrm{e} \\
\text { Statistic }\end{array}$ \\
\hline $\begin{array}{l}\text { Pemilihan Karir } \\
\text { Sebagai Akuntan }\end{array}$ & 226 & 38 & 32 & 70 & 12357 & 54.68 & .495 & 7.448 & 55.473 \\
\hline $\begin{array}{l}\text { Valid N } \\
\text { (listwise) }\end{array}$ & 226 & & & & & & & & \\
\hline
\end{tabular}

Berdasarkan data di atas, data statistik menunjukkan nilai tertinggi variabel Y sebesar 70 dan nilai terendah 32 dengan nilai rata-rata skor (mean) adalah 54,68. Standar deviasi (S) sebesar 7,448 dan varians $\left(\mathrm{S}^{2}\right)$ sebesar 55,473.

\section{Data Penghargaan Finansial}

Berdasarkan data yang dikumpulkan oleh peneliti, beberapa statistik deskriptif variabel X1 (penghargaan finansial) akan dijelaskan. 


\section{Tabel 3}

Statistik Deskriptif Variabel X1 (Penghargaan Finansial)

\begin{tabular}{|c|c|c|c|c|c|c|c|c|c|}
\hline & & & Desc & iptive $\mathbf{S t}$ & tistics & & & & \\
\hline & $\mathrm{N}$ & Range & $\underset{\mathrm{m}}{\operatorname{Minimu}}$ & $\underset{\mathrm{m}}{\text { Maximu }}$ & Sum & & & $\begin{array}{c}\text { Std. } \\
\text { Deviation }\end{array}$ & $\begin{array}{l}\text { Varian } \\
\text { ce }\end{array}$ \\
\hline & $\begin{array}{l}\text { Stati } \\
\text { stic }\end{array}$ & Statistic & Statistic & Statistic & Statistic & Statistic & $\begin{array}{l}\text { Std. } \\
\text { Error }\end{array}$ & Statistic & $\begin{array}{c}\text { Statisti } \\
\mathrm{c}\end{array}$ \\
\hline Penghargaan Finansial & 226 & 29 & 31 & 60 & 10313 & 45.63 & .379 & 5.698 & 32.465 \\
\hline Valid N (listwise) & 226 & & & & & & & & \\
\hline
\end{tabular}

Berdasarkan data di atas, data statistik menunjukkan nilai tertinggi variabel X1 memiliki nilai tertinggi 60 dan nilai minimum 31 dengan nilai rata-rata skor (mean) adalah 45,63. Standar deviasi (S) sebesar 5,698 dan varians $\left(\mathrm{S}^{2}\right)$ sebesar 32,465.

\section{Data Pertimbangan Pasar Kerja}

Berdasarkan data yang dikumpulkan oleh peneliti, beberapa statistik deskriptif variabel X2 (pertimbangan pasar kerja) akan dijelaskan.

\section{Tabel 4}

\section{Statistik Deskriptif Variabel X2 (Pertimbangan Pasar Kerja)}

\section{Descriptive Statistics}

\begin{tabular}{|c|c|c|c|c|c|c|c|c|c|}
\hline & \multirow{2}{*}{$\begin{array}{c}\mathrm{N} \\
\text { Statistic }\end{array}$} & \multirow{2}{*}{$\begin{array}{l}\text { Range } \\
\text { Statistic }\end{array}$} & \multirow{2}{*}{$\begin{array}{l}\text { Mini } \\
\text { mum } \\
\text { Statist } \\
\text { ic } \\
\end{array}$} & \multirow{2}{*}{$\begin{array}{l}\text { Maxi } \\
\text { mum } \\
\text { Statist } \\
\text { ic }\end{array}$} & \multirow{2}{*}{$\begin{array}{l}\text { Sum } \\
\begin{array}{c}\text { Statist } \\
\text { ic }\end{array} \\
\end{array}$} & \multicolumn{2}{|c|}{ Mean } & \multirow{2}{*}{$\begin{array}{c}\text { Std. } \\
\text { Deviation } \\
\text { Statistic }\end{array}$} & \multirow{2}{*}{$\begin{array}{l}\text { Variance } \\
\text { Statistic }\end{array}$} \\
\hline & & & & & & $\begin{array}{l}\text { Statist } \\
\text { ic }\end{array}$ & $\begin{array}{l}\text { Std. } \\
\text { Error }\end{array}$ & & \\
\hline $\begin{array}{l}\text { Pertimbangan } \\
\text { Pasar Kerja }\end{array}$ & 226 & 33 & 37 & 70 & 12256 & 54.23 & .455 & 6.842 & 46.818 \\
\hline Valid N (listwise) & 226 & & & & & & & & \\
\hline
\end{tabular}

Berdasarkan data di atas, data statistik menunjukkan nilai tertinggi variabel X2 memiliki nilai tertinggi sebesar 60 dan nilai terendah 31 dengan nilai rata-rata skor (mean) adalah 45,63. Standar deviasi (S) sebesar 5,698 dan varians $\left(\mathrm{S}^{2}\right)$ sebesar 32,465.

\section{Data Lingkungan Kerja}

Berdasarkan data yang dikumpulkan oleh peneliti, beberapa statistic deskriptif variabel X3 (lingkungan kerja) akan dijelaskan.

\section{Tabel 5}

\begin{tabular}{|c|c|c|c|c|c|c|c|c|c|}
\hline & \multicolumn{9}{|c|}{$\begin{array}{c}\text { Statistik Deskriptif Variabel X3 (Lingkungan Kerja) } \\
\text { Descriptive Statistics }\end{array}$} \\
\hline & \multirow{2}{*}{$\begin{array}{c}\mathrm{N} \\
\text { Statistic }\end{array}$} & \multirow{2}{*}{$\begin{array}{l}\text { Range } \\
\text { Statistic }\end{array}$} & \multirow{2}{*}{$\begin{array}{c}\text { Minimum } \\
\text { Statistic }\end{array}$} & \multirow{2}{*}{$\begin{array}{c}\text { Maximum } \\
\text { Statistic }\end{array}$} & \multirow{2}{*}{$\begin{array}{c}\text { Sum } \\
\text { Statistic } \\
\end{array}$} & \multicolumn{2}{|c|}{ Mean } & \multirow{2}{*}{$\begin{array}{c}\text { Std. Deviation } \\
\text { Statistic }\end{array}$} & \multirow{2}{*}{$\begin{array}{l}\text { Variance } \\
\text { Statistic } \\
\end{array}$} \\
\hline & & & & & & Statistic & Std. Error & & \\
\hline Lingkungan Kerja & 226 & 41 & 34 & 75 & 13921 & 61.60 & .493 & 7.415 & 54.988 \\
\hline Valid N (listwise) & 226 & & & & & & & & \\
\hline
\end{tabular}

Berdasarkan data di atas, data statistik menunjukkan nilai tertinggi variabel X3 memiliki nilai tertinggi sebesar 75 dan nilai terendah 34 dengan nilai rata-rata skor (mean) adalah 61,60. Standar deviasi $(\mathrm{S})$ sebesar 7,415 dan varians $\left(\mathrm{S}^{2}\right)$ sebesar 54,988.

\section{Uji Normalitas}

Hasil dari perhitungan uji normalitas menggunakan Kolomogorov-Sminov dengan program IBM SPSS versi 26 bahwa dapat disimpulkan bahwa keempat variabel berdistribusi normal. Hal ini dapat dibuktikan dengan hasil perhitungan dengan tingkat signifikansi sebesar 0,200. Tingkat 
signifikansi tersebut melebihi 0,05. Dengan demikian dapat disimpulkan bahwa data dari kempat variabel berdistribusi normal dan dapat digunakan dalam analisis selanjutnya.

\section{Uji Linearitas}

Pengambilan keputusan dapat dilakukan dengan uji linearitas dengan melihat hasil output pada tabel ANOVA dalam program statistik IBM SPSS versi 26. Hasil pengujian didapatkan signifikansi yang diperoleh dari penghargaan finansial dengan pemilihan karir sebagai akuntan adalah sebesar 0,525>0,05. Pertimbangan pasar kerja dengan pemilihan karir sebagai akuntan adalah sebesar $0,428>0,05$. Lingkungan kerja dengan pemilihan karir sebagai akuntan adalah sebesar $0,601>0,05$.

\section{Uji Regresi Berganda}

Peneliti melakukan uji regresi berganda guna untuk mengetahui ada tidaknya hubungan antara ketiga variabel independen terhadap variebel dependen secara mode linier. Berikut adalah uji regresi berganda dari penelitian ini :

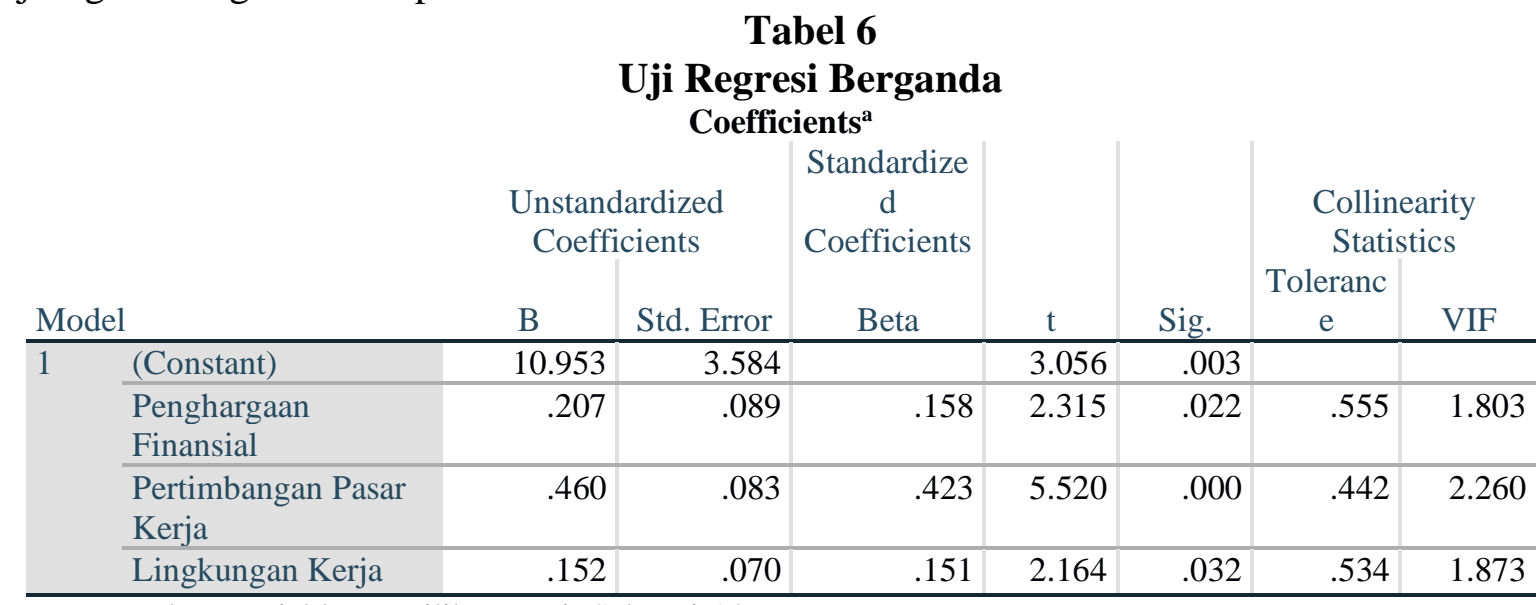

a. Dependent Variable: Pemilihan Karir Sebagai Akuntan

Dari data diatas, dapat diketahui persamaan regresi berganda yang diperoleh sebagai berikut :

$$
\dot{\mathbf{Y}}=\mathbf{1 0 . 9 5 3}+0,207 \mathrm{X}_{1}+0,460 \mathrm{X}_{2}+0,152 \mathrm{X}_{3}
$$

Sehingga dapat diartikan jika variabel penghargaan finansial, pertimbangan pasar kerja, dan lingkungan kerja memiliki nilai 0, pemilihan karir sebagai akuntan memiliki nilai sebesar 10.953. Nilai koefisien $\left(b_{1}\right)$, koefisien $\left(b_{2}\right)$, dan koefisien $\left(b_{3}\right)$ yang bernilai positif mengandung makna bahwa koefisien tersebut apabila :

1) Nilai konstanta sebesar 10.953 tersebut merupakan nilai tetap yang berarti bahwa pemilihan karir sebagai akuntan apabila tidak terdapat pengaruh dari variabel independen maka nilainya adalah sebesar 10.953 .

2) Nilai koefisien regresi penghargaan finansial (X1) terhadap pemilihan karir sebagai akuntan (Y) dapat diinterpretasikan sebesar 0,207 atau sebesar 20,7\% yang dapat dijelaskan bahwa setiap terjadi kenaikan $1 \%$ pada pemilihan karir sebagai akuntan dipengaruhi oleh penghargaan finansial sebesar $20,7 \%$.

3) Nilai koefisien regresi pertimbangan pasar kerja (X2) terhadap pemilihan karir sebagai akuntan (Y) dapat diinterpretasikan sebesar 0,460 atau sebesar $46 \%$ yang dapat dijelaskan bahwa setiap terjadi kenaikan $1 \%$ pada pemilihan karir sebagai akuntan dipengaruhi oleh pertimbangan pasar kerja sebesar $46 \%$. 
4) Nilai koefisien regresi lingkungan kerja (X3) terhadap pemilihan karir sebagai akuntan (Y) dapat diinterpretasikan sebesar 0,152 atau sebesar 15,2\% yang dapat dijelaskan bahwa setiap terjadi kenaikan $1 \%$ pada pemilihan karir sebagai akuntan dipengaruhi oleh lingkungan kerja sebesar $15,2 \%$

\section{Uji Hipotesis}

Pengujian hipotesis dilakukan dengan menggunakan SPSS versi 26. Berikut hasil pengujian hipotesis pada tabel berikut ini :

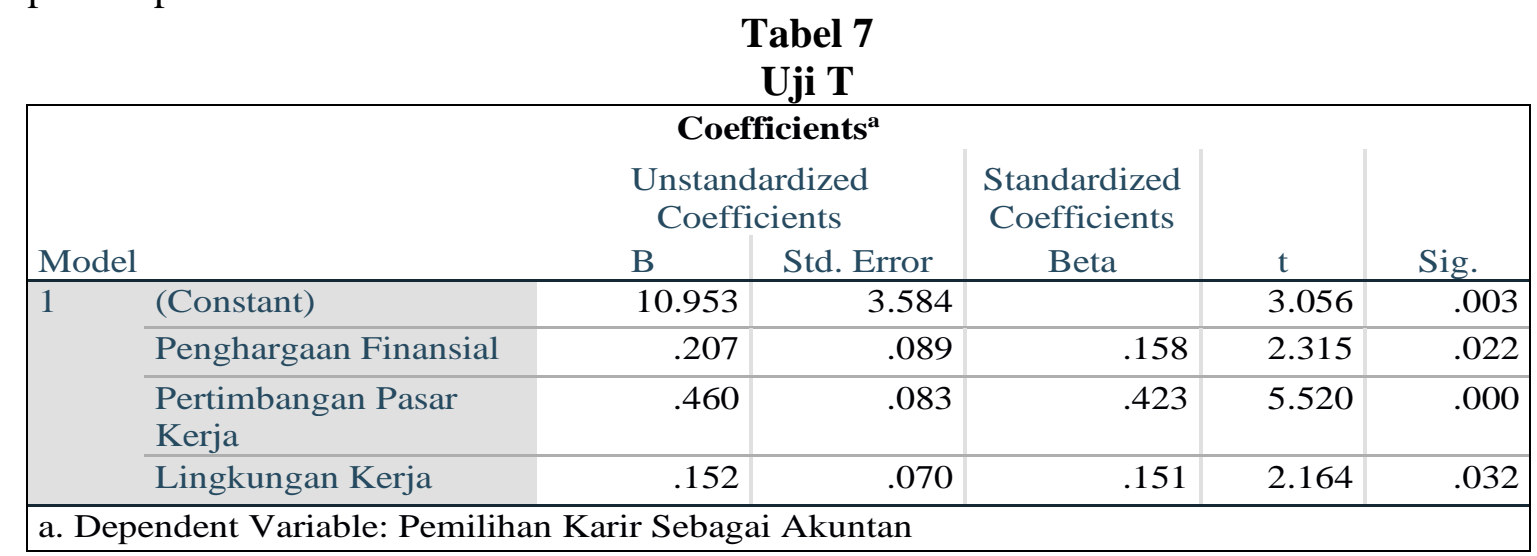
berikut :

Berdasarkan hasil penelitian uji t pada tabel diatas, maka dapat diinterpretasikan sebagai

1) Pengujian hipotesis pertama bertujuan untuk menguji apakah penghargaan finansial (X1) berpengaruh terhadap pemilihan karir sebagai akuntan. Berdasarkan tabel diatas diperoleh $t_{\text {hitung }}$ sebesar 2,315 dengan nilai tersebut lebih besar dari tabel 1,652 ( $\mathrm{df}=\mathrm{n}-\mathrm{k}-1$ atau 2263-1 =222) dengan nilai signifikansi 0,022 yang berarti lebih kecil dan tingkat signifikansi alpha 0,05. Dengan demikian Ho ditolak dan Ha diterima yang berarti penghargaan fianansial berpengaruh positif dan signifikan terhadap pemilihan karir sebagai akuntan

2) Pengujian hipotesis kedua bertujuan untuk menguji apakah pertimbangan pasar kerja (X2) berpengaruh terhadap pemilihan karir sebagai akuntan. Berdasarkan hasil dari tabel diatas di peroleh $t_{\text {hitung }}$ sebesar 5,520 dengan nilai tersebut lebih besar dari $t_{\text {tabel }} 1,652$ ( $\mathrm{df}=\mathrm{n}-\mathrm{k}-1$ atau 226-3-1 = 222) dengan nilai signifikansi 0,000 yang berarti lebih kecil dan tingkat signifikansi alpha 0,05. Dengan demikian Ho ditolak dan Ha diterima yang berarti pertimbangan pasar kerja berpengaruh positif dan signifikan terhadap pemilihan karir sebagai akuntan

3) Pengujian hipotesis ketiga bertujuan untuk menguji apakah lingkungan kerja (X3) berpengaruh terhadap pemilihan karir sebagai akuntan. Berdasarkan hasil dari tabel diatas di peroleh $t_{\text {hitung }}$ sebesar 2,164 dengan nilai tersebut lebih besar dari $t_{\text {tabel }} 1,652$ ( $d f=n-k-1$ atau 226-3-1 = 222) dengan nilai signifikansi 0,032 yang berarti lebih kecil dan tingkat signifikansi alpha 0,05. Dengan demikian Ho ditolak dan Ha diterima yang berarti lingkungan kerja berpengaruh positif dan signifikan terhadap pemilihan karir sebagai akuntan. 


\section{Tabel 8}

Uji F

\begin{tabular}{|c|c|c|c|c|c|c|}
\hline \multicolumn{7}{|c|}{$\mathbf{A N O V A}^{\mathbf{a}}$} \\
\hline Model & & Sum of Squares & df & Mean Square & $\mathrm{F}$ & Sig. \\
\hline \multirow[t]{3}{*}{1} & Regression & 5295.032 & 3 & 1765.011 & 54.524 & $.000^{\mathrm{b}}$ \\
\hline & Residual & 7186.389 & 222 & 32.371 & & \\
\hline & Total & 12481.420 & 225 & & & \\
\hline
\end{tabular}

Dari perhitungan tabel diatas maka didapatkan nilai $F_{\text {hitung }}$ sebesar 54,524. Nila $F_{\text {tabel }}$ pada taraf signifikansi 0,05 maka diperoleh nilai Ftabel sebesar 3,04, sehingga $F_{\text {hitung }} 54,524>F_{\text {tabel }}$ sebesar 3,04 yang artinya bahwa penghargaan finansial, pertimbangan pasar keja, dan lingkungan kerja secara simultan berpengaruh terhadap pemilihan karir sebagai akuntan.

\section{Analisis Koefisien Determinasi}

Dari hasil $\mathrm{R}$ square atau $\mathrm{R}^{2}$ pada tabel model summary sebesar 0,424. Hal ini dapat disimpulkan bahwa besarnya pengaruh variabel penghargaan finansial (X1), pertimbangan pasar kerja (X2), dan lingkungan kerja (X3) terhadap pemilihan karir sebagai akuntan (Y) adalah sebesar $42,4 \%$. Sedangkan sisanya sebesar $57,6 \%$ dapat dideskripsikan oleh variabel lain yang tidak diteliti oleh peneliti.

\subsection{Pembahasan}

\section{Pengaruh Penghargaan Finansial Terhadap Pemilihan Karir Sebagai Akuntan}

Penghargaan finansial adalah alat untuk memotivasi karyawan dalam bentuk balas jasa berupa uang, bonus, tunjangan, dana pensiun yang diberikan karena memiliki kontribusi kepada perusahaan atas pekerjaannya, memiliki keterampilan dan kinerja dalam memabantu perusahaan untuk mencapai tujuan. Hasil penelitian ini sejalan dengan hasil penelitian yang dilakukan oleh (Meiryani et al., 2020) membuktikan bahwa terdapat pengahargaan finansial memiliki pengaruh positif dan signifikan yang mempengaruhi minat mahasiswa dalam memilih karir menjadi akuntan publik.

\section{Pengaruh Pertimbangan Pasar Kerja terhadap Pemilihan Karir Sebagai Akuntan}

Pertimbangan pasar kerja merupakan suatu hal yang dapat mengkoordinasikan pertemuan antara pencari kerja dengan perusahaan yang memerlukan tenaga kerja sehingga pertimbangan pasar kerja turut menjadi faktor yang harus dipertimbangkan sebelum memilih pekerjaan. Hasil penelitian ini sejalan dengan penelitian lain yaitu Dibabe et al., (2015) dan Ambari \& Ramantha (2017) bahwa hasil penelitiannya menunjukkan bahwa pertimbangan pasar kerja berpengaruh positif dan signifikan terhadap pemilihan karir sebagai akuntan public

\section{Pengaruh Lingkungan Kerja terhadap Pemilihan Karir Sebagai Akuntan}

Lingkungan kerja merupakan seseorang yang melakukan aktivitas pekerjaannya baik dalam bentuk fisik maupun non fisik yang dapat mempengaruhi produktivitas dan kinerja karyawan. Oleh karena itu, mahasiswa dalam memutuskan pilihan karirnya sebagai akuntan maka lingkungan kerja akan menjadi sebuah aktivitas dengan waktu kerja yang dipergunakannya secara efektif sehingga mengalami peningkatan prestasi kerja pegawai.

Hasil penelitian yang didapatkan sejalan dengan penelitian lain yaitu Febriyanti (2019) bahwa lingkungan kerja berpengaruh positif dan signifikan terhadap pemilihan karir mahasiswa akuntansi sebagai akuntan. 


\section{Pengaruh Penghargaan Finansial, Pertimbangan Pasar Kerja, dan Lingkungan Kerja terhadap Pemilihan Karir Sebagai Akuntan}

Hasil penelitian ini yang didapatkan sejalan dengan penelitian oleh Jatmiko et al., (2019) yang menjelaskan bahwa mahasiswa akuntansi yang ingin menekuni karir sebagai akuntan publik terdapat beberapa aspek yang menjadi pendorong, yaitu penghargaan finansial, pertimbangan pasar kerja, pelatihan profesional, lingkungan kerja, pengakuan profesional, dan nilai-nilai sosial. Selanjutnya terdapat juga penelitian dari Ari et al., (2017) menunjukkan bahwa penghargaan finansial, pertimbangan pasar kerja, dan lingkungan kerja berpengaruh positif dan signifikan terhadap minat mahasiswa dalam berkarir sebagai akuntan publik. Kemudian hasil penelitian ini diperkuat oleh Azhiin \& Sukirno (2018) yang menjelaskan bahwa penghargaan finansial, pertimbangan pasar kerja, dan lingkungan kerja berpengaruh signifikan terhadap pemilihan karir di kalangan mahasiswa akuntansi.

\section{KESIMPULAN}

Dari hasil pengujian hipotesis dalam penelitian ini, maka dapat disimpulkan bahwa 1) Secara simultan terdapat pengaruh positif dan signifikan antara penghargaan finansial, pertimbangan pasar kerja, dan lingkungan kerja terhadap pemilihan karir sebagai akuntan. 2) Secara parsial ada pengaruh penghargaan fianansial yang signifikan terhadap pemilihan karir sebagai akuntan. 3) Kemudian secara parsial pertimbangan pasar kerja memiliki pengaruh yang signifikan terhadap pemilihan karir sebagai akuntan. 4) Dan terakhir secara parsial, terdapat pengaruh yang signifikan anatara lingkungan kerja terhadap pemilihan karir sebagai akuntan.

\section{Rekomendasi}

1) Dalam penelitian ini peneliti hanya melakukan pengujian terhadap karir akuntansi secara keselurahan saja, dan diharapkan untuk peneliti selanjutnya untuk dapat melakukan penelitian dengan menentukan salh satu jenis karir akuntan saja dengan menambahkan faktor-faktor yang lebih banyak lagi yang mempengaruhi pemilihan karir sebagai akuntan.

2) Peneliti selanjutnya disarankan bisa memperluas pengambilan sampel yang akan digunakan dalam penelitian, karena semakin besar jumlah sampel yang digunakan maka semakin representasif pula penelitian tersebut.

3) Diharapkan untuk penelitian selanjutnya saat melakukan penyebaran kuesioner dapat menambah metode wawancara atau tatap muka langsung dengan responden agar peneliti dapat memahami pernyataan kuesioner denga baik sehingga hasil yang diperoleh menjadi lebih akurat.

\section{DAFTAR PUSTAKA}

Abbott, L. F. (2013). Theories of the Labour Market and Employment : A Review. Industrial Systems Research.

Afandi, P. (2016). Concept \& Indicator Human Resources Management for Management Research. Deepublish (CV Budi Utama).

Ambari, I. P., \& Ramantha, I. W. (2017). Pertimbangan Pasar Kerja, Pengakuan Profesional, Nilai-Nilai Sosial, Lingkungan Kerja, Personalitas Pemilihan Karir Sebagai Akuntan Publik. E-Jurnal Akuntansi, 18(1), 705-734.

Andini, R., \& Amboningtyas, D. (2020). Analisis Faktor - Faktor yang Mempengaruhi Minat Mahasiswa Akuntansi Berkarir Sebagai Akuntan Publik: Studi Kasus pada Mahasiswa Akuntansi Universitas Pandanaran Rita. Jurnal Sains Sosio Humaniora, 4(1), 297-302. https://doi.org/https://doi.org/10.22437/jssh.v4i1.10462 
Ari, K. B. J., Wahyuni, M. A., \& Sulindawati, N. L. G. E. (2017). Pengaruh Faktor Gender, Pertimbangan Pasar Kerja, Lingkungan Kerja, Penghargaan Finansial dan Pelatihan Profesional Terhadap Minat Mahasiswa dalam Berkarir sebagai Akuntan Publik. E-Journal Universitas Pendidikan Ganesha, 8(2), 1-12. https://doi.org/http://dx.doi.org/10.23887/jimat.v8i2.13589

Asmoro, T. K. W., Wijayanti, A., \& Suhendro, S. (2016). Determinan Pemilihan Karir Sebagai Akuntan Publik Oleh Mahasiswa Akuntansi. Jurnal Dinamika Akuntansi Dan Bisnis, 2(2), 123-135. https://doi.org/10.24815/jdab.v2i2.4213

Azhiin, A. U., \& Sukirno. (2018). Factors Differentiating Career Selection among Accounting Students. Global Journal of Enterprise Information System, 1(1), 104-108. https://doi.org/10.18311/gjeis/2018/21039

Bahri, S. (2018). Pengaruh Kepemimpinan, Lingkungan Kerja, Budaya Organisasi, dan Motivasi Terhadap Kepuasan Kerja Yang Berimplikasi Terhadap Kinerja Dosen,. CV. Jakad.

Byrne, M., Willis, P., \& Burke, J. (2012). Influences on school leavers' career decisions Implications for the accounting profession. International Journal of Management Education, 10(2), 101-111. https://doi.org/10.1016/j.ijme.2012.03.005

D.Viviers, \& Schalkwyk, H. Van. (2002). Success With English Language and Communication Skills. Maskew Miller Longman.

Dibabe, T. M., Wubie, A. W., \& Wondmagegn, G. A. (2015). Factors that Affect Students ' Career Choice in Accounting: A Case of Bahir Dar University Students. Research Journal of Finance and Accounting, 6(5), 146-154. http://www.iiste.org/Journals/index.php/RJFA/article/view/20781

Espa, V., Arista, S. M., \& Sari, G. F. (2016). Pengaruh Faktor-Faktor Penghargaan Finansial (Gaji), Lingkungan Kerja, Pelatihan Profesional, Nilai-Nilai Sosial, Pertimbangan Pasar Kerja, dan Personalitas Terhadap Pemilihan Karir Bagi Mahasiswa Akuntansi. Jurnal Audit Dan Akuntansi, 5(2), 29-58.

Hambali, I. R., Wuryandini, A. R., \& Noholo, S. (2018). Pengaruh Penghargaan Financial,Lingkungan Kerja, dan Pertimbangan Pasar Kerja Terhadap Pemilihan Karir Sebagai Akuntan Publik Pada Mahasiswa Akuntansi (Studi Pada Perguruan Tinggi Negeri Dan Swasta di Provinsi Gorontalo). The SAGE Dictionary of Social Research Methods, 1(2), 1-13. https://doi.org/10.4135/9780857020116.n162

Hariandja, M. T. E. (2002). Manajemen Sumber Daya Manusia: Pengadaan, Pengembangan, Pengkompensasian, dan Peningkatan Produktivitas Pegawai. Grasindo.

Hermino, A. (2013). Asesmen Kebutuhan Organisasi Persekolahan : Tinjauan Perilaku Organisasi Menuju Comprehensive Multilevel Planning. PT Gramedia.

Iis, E., Sulaiman, S., \& Arifin, A. (2019). The Coherence Model of Self-Efficacy as the Intervening Variable of Work Environment and Leadership Behavior on the Employees Performance of Aceh Government Planning Agency. ICOFEB 2018: Proceedings of the 1st International Conference on Finance Economics and Business, ICOFEB 2018, 12-13 November 2018, Lhokseumawe, Aceh, Indonesia, 1-7. https://doi.org/10.4108/eai.12-112018.2288777

IKATAN AKUNTANSI INDONESIA. (n.d.). SIARAN PERS IAI APAFEST 2020: TANTANGAN PROFESI DAN EKONOMI INDONESIA PASCA COVID-19. Http://Iaiglobal.or.Id/. Retrieved November 26, 2020, from http://iaiglobal.or.id/v03/beritakegiatan/detailberita-1325-siaran-pers-iai-apafest-2020--tantangan-profesi-dan-ekonomiindonesia-pasca-covid19

Jatmiko, B., Machmuddah, Z., Suryani, A., Suhana, S., \& Laras, T. (2019). Career Choice as a 
Public Accountant in Accounting Students in the City of Semarang Indonesia: Aspects that are Considered. International Journal of Accounting and Taxation, 7(2), 20-26. https://doi.org/10.15640/ijat.v7n2a3

Kartono. (2019). Kepribadian dan politik Bank Perkreditan Rakyat. Deepublish (CV Budi Utama).

Malik. (2016). Bimbingan Konseling di Sekolah Dasar. Kencana Prenada Media Group,.

Malik, N. (2018). Dinamika Pasar Tenaga Kerja Indonesia. Universitas Muhammadiyah Malang.

Marliyah, L., Fransisca. I. R. Dewi, \& Suyasa, P. T. Y. S. (2004). Jurnal Provitae. Yayasan Obor Indonesia.

Marnisah, L. (2019). Hubungan Industrial dan Kompensasi : Teori dan Praktik. Deepublish (CV Budi Utama).

Meddour, H., Abdo, A. A. M., Majid, A. H. A., Auf, M. A. A., \& Aman, A. M. (2016). Factors affecting career choice among undergraduate students in universitas Indonesia. International Journal of Economic Perspectives, 10(4), 630-644. http://www.econsociety.org

Meiryani, Bening, D. A., Wahyuningtias, D., \& Maryani. (2020). The Effect Of Financial Award On Student Interests In Choosing Career To Be Public Accountant. Talent Development \& Excellence, 12(1), 1593-1601.

http://search.ebscohost.com/login.aspx?direct=true \&db=s3h\&AN=144307263\&lang=ja\&sit $\mathrm{e}=$ ehost-live

Mu'ah, \& Masram. (2014). Loyalitas Pelanggan: Tinjauan Aspek Kualitas Pelayanan dan Biaya Peralihan. Zifatama Jawara.

Mulyadi. (2007). Sistem Perencanaan dan Pengendalian Manajemen : Sistem Pelipatganda Kinerja Perusahaan. Salemba Empat.

Nikmatin, N., Darwin, \& Purba, S. (2019). The Influence of Utilization of Information and Communication Technology, Career Development and Work Environment on Teacher Job Stress in SDN Cluster 1 and 3 Bandar Subdistrict, Bener Meriah Regency, Aceh Province. ACEIVE 2018: Proceedings of the 2nd Annual Conference of Engineering and Implementation on Vocational Education, 1-7. https://doi.org/10.4108/eai.3-112018.2285645

Pearce, J. A., \& Robinson, R. B. (2008). Manajemen Strategis : Formulasi, Implementasi, dan Pengendalian. Salemba Empat. https://doi.org/978-979-691-462-3

Prieto, G. (2020). Myth and Reality in the U.S. Immigration Debate: The Myths and Realities of Immigration in the United States. Routledge.

Prihantoro, A. (2019). Peningkatan Kinerja Sumber Daya Manusia Melalui Motivasi, Disiplin, Lingkungan Kerja, dan Komitmen. Deepublish (CV Budi Utama).

Rafsandjani, \& Firdian, R. (2017). Pengantar Bisnis Bagi Pemula. Kautsar Abadi.

Riyadi, S. (2018). Faktor Peningkatan Kinerja Melalui Job Stress. Zifatama Jawara.

Robbins, S. P., \& Judge, T. A. (2017). Organizational Behavior. Pearson Education Limited.

Saputra, A. J. (2018). Pengaruh Persepsi Mahasiswa Akan Minat, Motivasi, Pelatihan

Profesional, Gender Dan Lingkungan Pekerjaan Terhadap Pilihan Karir Akuntan Publik Dan Non Publik. Jurnal Riset Akuntansi Mercu Buana, 4(2), 126. https://doi.org/10.26486/jramb.v4i2.478

Setianto, A. I., \& Harahap, Y. A. (2017). Factors Affecting the Interests of Accounting Students Study Program Selection Career Public Accountants. Journal of Applied Managerial Accounting, 1(1), 51-61. https://doi.org/10.30871/jama.v1i1.1238

Sugiyono. (2017). Statistika Untuk Penelitian. Alfabeta. 
Suindari, N. M., \& Purnama Sari, A. P. A. M. (2018). Kinerja Akademik, Pertimbangan Pasar Kerja, Minat Berkarir Akuntan Publik. Jurnal Aplikasi Akuntansi, 3(1), 022-047. https://doi.org/10.29303/jaa.v3i1.31

Suprihanto, J. (2018). Manajemen. Gajah Mada University Press.

Surajiyo, Nasruddin, \& Paleni, H. (2020). Penelitian Sumber Daya Manusia, Pengertian, Teori, dan Aplikasi : Menggunakan IBM SPSS 22 For Windows. Deepublish (CV Budi Utama).

Susanti. (2021). Persepsi dan Cara Pemberian Pendidikan Seksual Pada Anak TK. Adab (CV. Adanu Abimata).

Susanto, Y. (2017). Peran Kepemimpinan dalam Pengelolaan Koperasi. Deepublish (CV Budi Utama).

Utama, Z. M. (2020). Manajemen Sumber Daya Manusia: Konsep Dasar Dan Teori. UNJ Press.

Wibowo, Y. K. (2020). Keselamatan dan Kesehatan Kerja ZEROSICKs Mekatronika. FAM Group. 